Western North American Naturalist 70(4), (C) 2010, pp. 446-456

\title{
CONSIDERATIONS FOR WOOD RIVER SCULPIN CONSERVATION: HISTORICAL OCCURRENCE AND SAMPLING EFFICIENCY
}

\author{
Donald W. Zaroban ${ }^{1}$
}

\begin{abstract}
Records of Wood River sculpin (Cottus leiopomus) from 1893 to 2003 were examined and new data were gathered in 2004 and 2006 to estimate the species' historical range and to search for evidence of changes in its occurrence. Detections of Wood River sculpin were reported in 49 subwatersheds, primarily in the Idaho Batholith ecoregion. The remainder of the Wood River basin was classified as either potential historic range or unknown. Mark-recapture sampling was conducted to estimate the efficiency of electrofishing as a method to detect this sculpin. Sampling efficiency was calculated for 1 upstream pass and 1,2, and 3 bidirectional passes. A mean sampling efficiency of $45.9 \%$ (range 15.4\%-63.0\%) was achieved using 3 bidirectional passes, block nets, and 0.942 minutes of electrofishing per $\mathrm{m}^{2}$ of stream surface. Efficiency declined an average of $38 \%$ between electrofishing passes. The rates and reduced efficiencies observed between passes suggest that multiple passes and visits are needed to reliably estimate sculpin presence or absence.
\end{abstract}

Key words: Wood River sculpin, Cottidae, historical range, sampling efficiency, sampling effort, species conservation.

RESUMEN.-Se examinaros registros observacionales de los charrascos espinosos Wood River (Cottus leiopomus) de 1893 a 2003 y nuevos datos fueron reunidos en 2004 y 2006 para estimar su extensión histórica y buscar evidencia de cambios en su presencia. Se ha reportado la detección de charrascos espinosos Wood River en 49 subcuencas, principalmente en la ecorregión del Batolito de Idaho. El resto de la cuenca del Wood River fue clasificado, ya sea como posible distribución histórica o como desconocida. Se llevó a cabo un muestreo de marcaje y recaptura para estimar la eficiencia de la electropesca como método para detectar el charrasco espinoso. Se calculó la eficiencia del muestreo para un pase río arriba y 1, 2 y 3 pases bidireccionales. Se alcanzó una eficiencia promedio del muestreo de 45.9\% (del 15.4 al $63.0 \%$ ) usando 3 pases bidireccionales, redes de bloqueo y la aplicación de corriente eléctrica por 0.942 minutos por metro cuadrado de superficie del arroyo. La eficiencia disminuyó 38\% en promedio entre pases de electropesca. Las tasas y la reducción de eficiencia observadas entre pases sugieren que múltiples pases y visitas son requeridos para estimar con precisión la presencia o ausencia del charrasco espinoso.

Investigations of fish populations in Idaho and the Pacific Northwest typically focus on salmonids. To protect the biological integrity of Idaho's aquatic ecosystems, investigations of nonsalmonid taxa need to be conducted. The Wood River sculpin (Cottus leiopomus) is endemic to the Wood River basin of south central Idaho (Simpson and Wallace 1982). It is a protected nongame species and is considered vulnerable primarily because of its limited distribution and habitat loss (Idaho Department of Fish and Game 2005). Current threats include water quality impairment, habitat loss and fragmentation, nonnative piscivorous fish, floodplain encroachment, and flow alterations from stream channelization, diversions, and dams (Buhidar 2002, Claire 2005a, 2005b, Meyer et al. 2008).

Despite its vulnerability, the Wood River sculpin has received little study or conservation attention. No rangewide studies of Wood River sculpin occurrences have been conducted until recently (Meyer et al. 2008). Moreover, the historical record of Wood River sculpin occurrence is incomplete and much of the available information is anecdotal. Despite these limitations, an evaluation of these records can be used to estimate the potential historical range of the Wood River sculpin within the Wood River basin and may reveal temporal changes in its occurrence.

The sampling method recommended and typically used in previous Wood River sculpin investigations is electrofishing (Merkley and Griffith 1993, Abbruzzese and Henderson 1999, Meyer et al. 2008), but evaluations of electrofishing efficiency are lacking. Failure to detect a species when it is present is an issue in species conservation sampling (Bayley and Peterson 2001, MacKenzie 2005). An investigator's inability

${ }^{1}$ Idaho Department of Environmental Quality, 1410 N. Hilton Street, Boise, ID 83706. E-mail: don.zaroban@deq.idaho.gov 


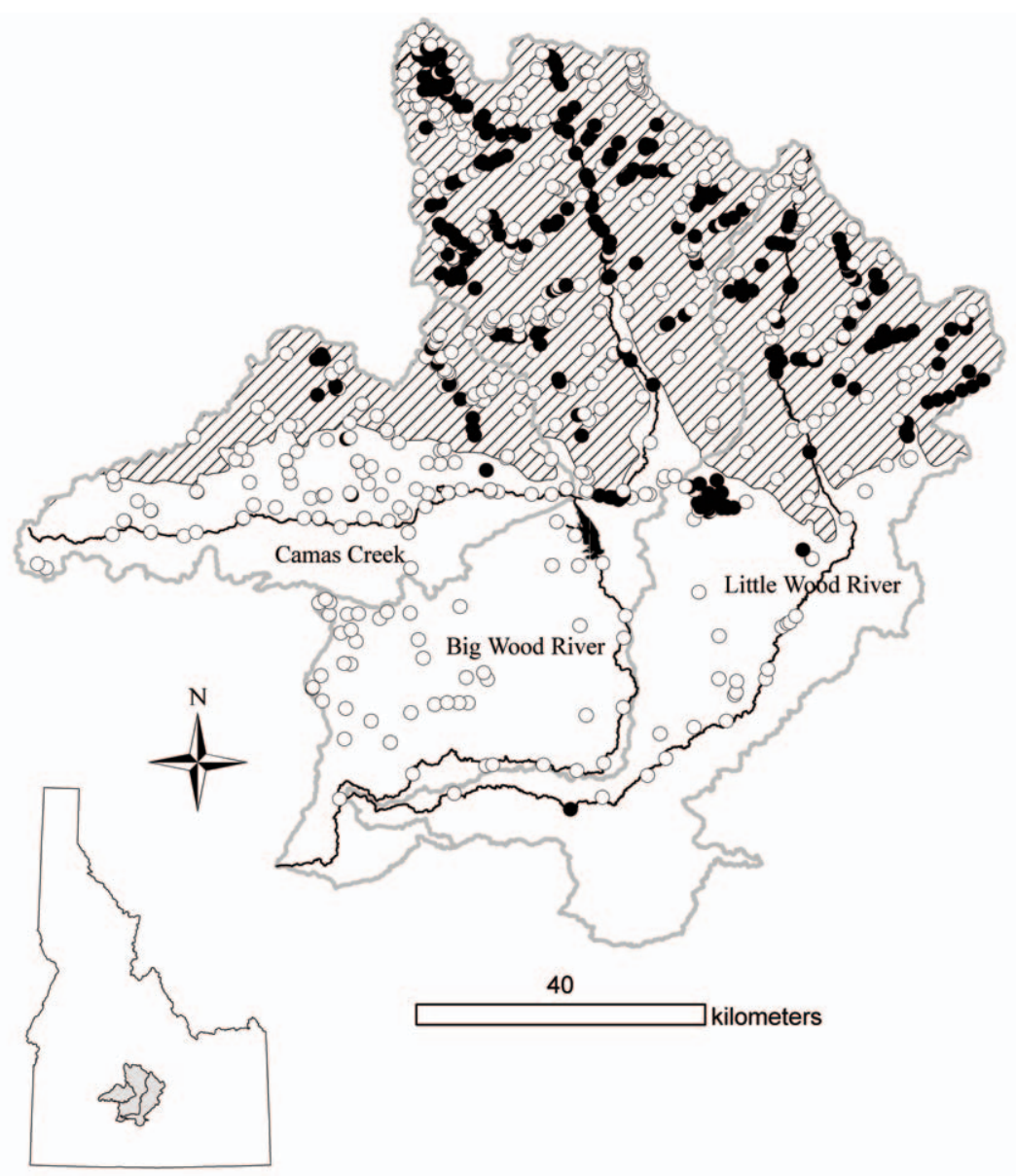

Fig. 1. Location of Wood River basin and distribution of 866 Wood River sculpin sampling events. Filled circles indicate detections and empty circles indicate nondetections of Wood River sculpin. The hatched area denotes the Idaho Batholith ecoregion and the unshaded area is the Snake River Plain ecoregion. Watershed boundaries are indicated by gray lines, and mainstem streams are indicated by black lines.

to find a species when it is present can hinder conservation efforts by failing to accurately describe occurrence. Freshwater sculpins, genus Cottus, are small bottom-dwelling fish that lack an air bladder, possess dark, mottled coloration, and exhibit cryptic behavior (Moyle and Cech 2000). These characteristics make them inconspicuous and reduce their capture probability (Bayley and Peterson 2001).

The goal of this study was to provide preliminary occurrence and sampling efficiency information for the Wood River sculpin. The objectives were to describe the potential historical range within the Wood River basin based on detection reports, identify areas where occurrence may have changed, estimate the efficiency of electrofishing as a method to collect Wood
River sculpins, and report the effort needed to achieve that efficiency. The findings can be used to identify areas where additional presenceabsence sampling is needed.

\section{Methods}

\section{Study Area}

The Wood River basin covers approximately $8647 \mathrm{~km}^{2}$ in south central Idaho (Fig. 1; Idaho Department of Water Resources 2007) and comprises the Big and Little Wood rivers and Camas Creek. The basin is $65 \%$ publicly owned, primarily by the Bureau of Land Management $(39 \%)$ and the USDA Forest Service $(22 \%)$. The Big Wood River originates in the Smoky Mountains south of Galena Summit at an elevation 
of $2743 \mathrm{~m}$ and empties into the Snake River approximately $4.8 \mathrm{~km}$ west of Tuttle, Idaho, at an elevation of $838 \mathrm{~m}$. The basin is located on southern Idaho's Batholith and Snake River Plain ecoregions with land cover of tundra and alpine meadows at the highest elevations transitioning through grand fir (Abies grandis [Douglas ex D. Don] Lindl.) and Douglas-fir (Pseudotsuga menziesii [Mirb.] Franco) forest to sagebrush steppe at the lowest elevations (McGrath et al. 2001). The Idaho Batholith portions of the basin are primarily to partially glaciated peaks, high mountains, and foothills; whereas, the Snake River Plain portions are primarily nonglaciated foothills, terraces, and alluvial fans including lava flows and basaltcapped buttes (McGrath et al. 2001). Mean annual precipitation ranges from 23 to $150 \mathrm{~cm}$ per year (Oregon State University 1998).

\section{Range Estimation}

To estimate the potential historical range of Wood River sculpin, I examined existing records from natural history museums, academic institutions, and public agencies from 1893 to 2006 (Table 1). A sampling event was defined as a search conducted on a specified date at a particular point or reach of a stream. The only records considered were those that explicitly stated whether Wood River sculpins were present or apparently absent and those that provided the year of collection and sufficient information to allow geographic coordinates to be assigned to the sampling event.

To supplement the exisiting records, I also conducted a systematic, rangewide field survey of Wood River sculpin occurrences in 2004 and 2006. In my survey, 166 wet stream reaches that complement the recent work of Meyer et al. (2008) were searched. Stream reaches were chosen based on a stratified randomized design with ecoregion and stream order (following Strahler 1957) as the strata. Level III ecoregion (McGrath et al. 2001) was selected as a stratum to account for physiographic, geologic, and climatic differences between the Idaho Batholith and Snake River Plain ecoregions. Stream order was selected as a stratum to help account for reported differences in sculpin distribution associated with wetted width and channel gradient (Bond 1963, Jones 1972). Streams were classified as 1st to 2 nd order, 3rd to 4 th order, or 5 th to 6 th order. Although stream order is a crude surrogate for size and gradient of a stream (Hughes and Omernik 1981), it is widely used as a stratum in study designs for regional stream surveys and appears useful if its application is confined within drainages and ecoregions (Herlihy et al. 2000, Olsen and Peck 2008). I estimated the number of stream-reach searches needed to describe contemporary Wood River sculpin occurrence by using the following inputs: the frequency of sculpin detections reported in a redband trout (Oncorhynchus mykiss) survey in the Big and Little Wood river drainages (Abbruzzese and Henderson 1999) and the modeled estimates of occurrence prediction accuracy (McKenney et al. 2002). The estimate was $>100$. Random points were selected from 1:100,000-scale hydrography performed by the Environmental Monitoring and Assessment Program staff at the Environmental Protection Agency laboratory in Corvallis, Oregon. The random points were located in the field using a GPS receiver.

Merkley and Griffith (1993) evaluated kick sampling, frame netting, and electrofishing and concluded that electrofishing was the most effective method to sample Wood River sculpins. To detect sculpins in the present study, single upstream passes were made using pulsed-DC electrofishing. Electrofishing effort averaged 11.7 minutes (range 1.5-41.2) per stream reach. The mean length of these reaches was $103 \mathrm{~m}$ (range 18.3-563) and mean width was $4.7 \mathrm{~m}$ (range 3.0-58.8). Stunned fish were dipnetted and held in buckets until the end of the pass. At the end of the electrofishing pass, all fish caught were anesthetized with $45 \mathrm{mg} \cdot \mathrm{L}^{-1}$ tricaine methanesulfonate (MS-222). Once lethargic, all fish were counted by species, measured to the nearest millimeter for total length, and placed in a recovery bucket. Recovered fish were returned to the stream. Fish retained for taxonomic verification were identified and archived at the Orma J. Smith Museum of Natural History at the College of Idaho (Caldwell, ID).

Finally, I combined the results from my field surveys with existing records to compare detections and nondetections across time. Sampling records were aggregated by subwatershed (USGS and USDA-NCS 2009) and sorted by date. There are 99 subwatersheds delineated in the Wood River basin with a mean surface area of 8738 ha (range 3513 to 25,298 ha; Idaho Department of Water Resources 2008). To estimate potential historical range, subwatersheds were classified as to whether Wood River 
TABLE 1. Sources consulted for historical records of Wood River sculpin detections. Year(s) is the period of record for the source.

\begin{tabular}{ll}
\hline Year(s) & \multicolumn{1}{c}{ Source } \\
\hline 1893 & $\begin{array}{l}\text { GILBERT C.H., AND B.W. EvErmanN. 1894. A report upon investigations in the Columbia River basin, } \\
\text { with descriptions of four new species of fishes. Bulletin of the United States Fish Commission. Volume } \\
\text { XIV, for 1894. U.S. Government Printing Office, Washington, DC. }\end{array}$ \\
$1977-1978$ & $\begin{array}{l}\text { BRuns, D.A., AND G.W. MinsHaLL. 1979. Effects of drought on the Big Wood River, Idaho. Idaho State } \\
\text { University. Walla Walla District, U.S. Army Corps of Engineers, Walla Walla, WA. }\end{array}$ \\
& $\begin{array}{l}\text { Francis, L.J., AND T.C. BJORNn. 1979. Aquatic resources in The Nature Conservancy portion of Silver } \\
\text { Creek. Forest, Wildlife and Range Experiment Station Technical Report 9, Idaho Cooperative Fishery } \\
\text { Research Unit, University of Idaho, Moscow, ID. }\end{array}$
\end{tabular}

1982-1983 GRUNDER, S.A. 1985. Biotic responses to sediment removal in a tributary of Silver Creek, Idaho. Master's thesis, Idaho State University, Pocatello, ID.

1986 Grunder, S.A., L. BARRETT, AND R.J. BELL. 1987. Regional fisheries management investigations: Region 4 river and stream investigations. Idaho Department of Fish and Game, Jerome, ID.

1987 Grunder, S.A., S.C. Elam, and R.J. BELL. 1989. Regional fisheries management investigations: Region 4 river and stream investigations. Idaho Department of Fish and Game, Jerome, ID.

1989 PartRidge, F.E., AND C.E. CoRsi. 1990. Regional fisheries management investigations: Region 4 rivers and streams investigations. Idaho Department of Fish and Game, Jerome, ID.

1992 MerkLey, K., AND J.S. Griffith. 1993. Densities and habitat utilization of Wood River sculpin (Cottus leiopomus) on three Nature Conservancy preserves in Idaho, Idaho State University, Pocatello, ID.

1992 WarREN, C.D., AND F.E. PaRTRIDGE. 1994. Regional fisheries management investigations: Region 4 rivers and streams investigations. Idaho Department of Fish and Game, Jerome, ID.

1971-1993 PARTRIDGE, F.E. 1995. Saving all the pieces: Idaho interagency conservation/pre-listing effort. Idaho Department of Fish and Game, Boise, ID.

1993 Partridge, F.E., AND C.D. Warren. 1995. Regional fisheries management investigations: Magic Valley Region rivers and streams investigations. Idaho Department of Fish and Game, Jerome, ID.

1996 GRIFFITH, J.S. 1996. Wood River sculpin (Cottus leiopomus): abundance and distribution on portions of the Ketchum Ranger District of the Sawtooth National Forest and the Sawtooth National Recreation Area, Ketchum, ID.

1995 Warren, C.D., F.E. Partridge, and K.A. Frank. 1997. Regional fisheries management investigations: Magic Valley Region rivers and streams investigations. Idaho Department of Fish and Game, Jerome, ID

1999 AbbruZzese, C., ANd R. Henderson. 1999. Fish surveys for redband trout in the Big and Little Wood River drainages. U.S. Forest Service Sawtooth National Forest and Sawtooth National Recreation Area, Ketchum, ID.

1971-1999 U.S. Forest Service, U.S. Fish and Wildlife Service, U.S. Bureau of Land Management, Idaho Department of Fish and Game and State of Idaho. 1999. Habitat conservation assessment and strate gy: Wood River sculpin (Cottus leiopomus) [draft]. U.S. Bureau of Land Management, Shoshone, ID.

1934-1950 University of Michigan Museum of Zoology catalog numbers: 130451, 158923, 161841, 161843, 161847.

1971-1990 Richard L. Wallace fish collection catalog numbers: 676, 704, 716, 832, 1164, 1188, 1255, 1256, 1257, $1347,1348,1602,1662,1738$.

1893 National Museum of Natural History catalog number: 45389.

1893 California Academy of Sciences, Stanford University catalog number: 1178.

1991-2004 Orma J. Smith Museum of Natural History, College of Idaho catalog numbers: 68048-68049, 68051, 68053, 68124, 68126, 68129, 68155, 68243, 68317-68319, 68325, 68328-68329, 68334, 68339, 68619, 68620, $68653,68655,68658,68660,68662,68666-68669,68678,68680,68893,68904,68916,68921,69704,69708-$ 69710, 69712, 70029, 70042, 70245, 70275, 70433-70436, 70450, 70453, 70455-70471, 70992, 71007, 81142, 81155-81162, 81722-81724, 81729-81731, 81744.

1993-2006 Idaho Department of Environmental Quality Beneficial Use Reconnaissance Program Database.

2003 Idaho Department of Fish and Game Wood River Sculpin Status Assessment Database.

1993-2006 U.S. GeOLOGICAL SurveY. "Fish on”-Line [online database]. USGS-NBII. Available from: http://great basin.wr.usgs.gov/fish/FormSearch.aspx 
TABLE 2. Distribution of reported Wood River sculpin sampling events.

\begin{tabular}{lcccccc}
\hline & \multicolumn{2}{c}{ Ecoregion } & & \multicolumn{3}{c}{ Stream order } \\
\cline { 2 - 3 } & Snake River Plain & Idaho Batholith & & 1st-2nd & 3rd-4th & 5th-6th \\
\hline Dry events & 126 & 76 & & 135 & 49 & 18 \\
Wet events & 114 & 550 & & 397 & 209 & 58 \\
$\quad$ detections & 58 & 342 & & 201 & 164 & 35 \\
nondetections & 56 & 208 & & 196 & 45 & 23 \\
\hline
\end{tabular}

sculpins had been detected, as having potential for sculpin occurrence, or as unknown. Subwatersheds with reported detections were included in the historical range. Subwatersheds that may be hydrologically connected to or that bordered subwatersheds with detections were classified as potential range. The remaining subwatersheds contained no reported sampling events or only periodic nondetections and were classified as unknown. Land ownership was estimated for each of these range classes to help identify potential conservation opportunities and to inform managers interested in Wood River sculpin conservation. Ownership estimates were based on the "Stewardship and Conservation Status of Idaho" GIS data layer prepared by the Landscape Dynamics Lab (1999).

\section{Sampling Efficiency}

Repeated searches at a particular site are used to estimate species detection probability (MacKenzie et al. 2002, Tyre et al. 2003). Since no reports of repeated searches for Wood River sculpins were found, the efficiency of pulsedDC electrofishing to sample sculpins was evaluated. Mark-recapture sampling was conducted in study reaches where sculpins had been detected previously. Tandem pairs of study reaches (members of a pair were longitudinally adjacent) were established by installing 3 block nets at 7 locations in 5 streams. Habitat complexity was low in these study reaches. All streams were wadeable and contained primarily riffle habitat near base flow levels with little or no woody debris, vegetation, or undercut banks. These reaches were 9.6-45.0 m long and 1.8-3.8 m wide. In each study reach, sculpins were collected, anesthetized, measured for total length, marked differentially between the paired study reaches with a right or left pectoral fin clip, and placed in an aerated recovery bucket. As they recovered, the marked sculpins were replaced in the study reach from which they were taken. One or 2 days after the release of the marked sculpins, each study reach was electrofished upstream; all fish collected were placed in an aerated bucket. The study reach was then electrofished downstream and all fish collected (including those trapped in the downstream block net) were placed in a separate aerated bucket. Electrofishing time was regularly noted during each pass to ensure equal electrofishing effort. The fish were then anesthetized, and each sculpin was inspected for a pectoral fin clip, measured for total length, and placed in an aerated recovery bucket. No mortalities were observed among the marked fish. The fish were released downstream of the paired study reaches once they had recovered, typically within 10 minutes. This recapture procedure was repeated twice, resulting in 6 removal passes through each study reach. Total electrofishing effort was 27.7-74.1 minutes per study reach.

Observed sampling efficiency was calculated as the number of marked sculpins recaptured in each removal pass divided by the number of marked fish available (Peterson et al. 2004). Sampling efficiency was calculated for one upstream pass and 1, 2, and 3 bidirectional passes. Large fish are more susceptible to electrofishing than small fish (Reynolds 1996). To assess size bias, the marked fish were classified as small $(\leq 59 \mathrm{~mm})$ or large $(\geq 60 \mathrm{~mm})$. The statistical significance of differences in sampling efficiency between these size classes was evaluated with a 2 -sample $t$ test. The significance of differences in mean total length between the first, second, and third upstream-downstream passes was evaluated with ANOVA. The effort needed to achieve the efficiency levels I observed was calculated as the mean minutes of electrofishing per square meter of stream reach sampled.

\section{RESUlts}

Records from 866 sampling events were obtained and compiled by ecoregion and stream order (Table 2). Sampling covered the years from 1893 to 2006 but only 92 sampling events (11\%) occurred prior to 1990 . Wood River 


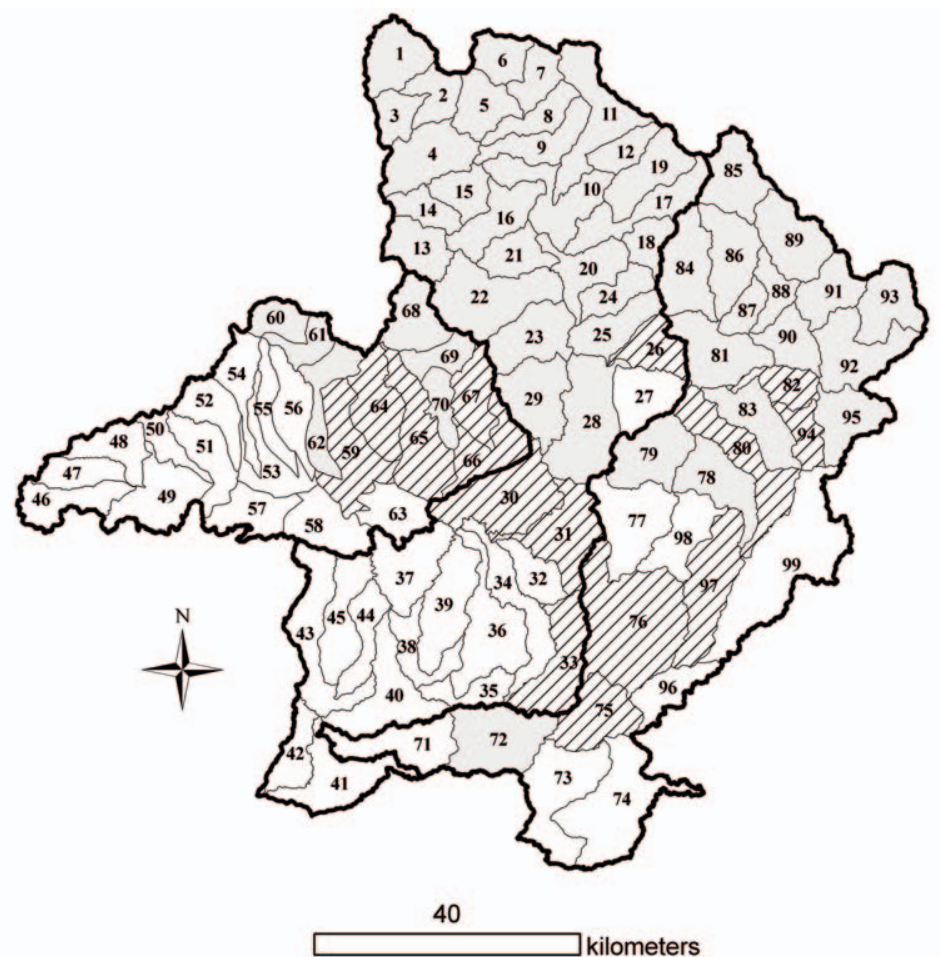

Fig. 2. Estimated historical range of the Wood River sculpin based on subwatershed aggregations of reported detections. Shaded subwatersheds contain reported detections. Potential range subwatersheds (hatched subwatersheds) border or may be hydrologically connected to those containing detections. Subwatersheds classified as unknown (unshaded subwatersheds) contain either no reported sampling events or a majority of sampling events at dry sites. Subwatershed boundaries are denoted by gray lines. Numbers refer to subwatersheds named in Table 3.

sculpins were detected in 400 of these events, with the majority of detections within or just downstream of the Idaho Batholith ecoregion (Fig. 1). Dry streams were reported in 53\% of the Snake River Plain events and $12 \%$ of the Idaho Batholith events. The percentage of dry streams varied little by stream order: $25 \%$ for 1st- to 2 nd-order, $19 \%$ for 3rd- to 4 th-order, and $24 \%$ for 5 th- to 6 th-order streams. Sculpin detections in the Snake River Plain ecoregion were concentrated in the Big Wood River near Stanton Crossing and in Silver and Fish Creeks of the Little Wood River watershed. Idaho Batholith nondetections typically were in headwater stream reaches or small tributaries. The percentage of sampling events in which sculpins were detected was highest for 3rd- to 4th-order streams (78\%), followed by 5th- to 6th- $(60 \%)$ and 1st- to 2 nd- $(51 \%)$ order streams.

Wood River sculpins were detected in 49 subwatersheds (Table 3). Among subwatersheds containing no reported detections, 15 were classified as potentially being within the historical range, and 35 were classified as unknown (Fig. 2). In subwatersheds with sculpin detections, 5 had only nondetection sampling events following a detection (Table 4). In 12 of the 15 subwatersheds classified as potential historical range, $87 \%$ of the sampling events occurred on dry streams (Table 4). Nine subwatersheds classified as unknown contained no sampling events, and among the other subwatershelds, $82 \%$ of the sampling events were at dry sites. Primary landowners in subwatersheds containing sculpin detections are the USDA Forest Service $(47 \%)$, private individuals or organizations $(25 \%)$, and the Bureau of Land Management $(23 \%)$. In subwatersheds classified as potential range or unknown, the primary landowners are the Bureau of Land Management (49\% and 52\%, respectively), private individuals or organizations (44\% and $42 \%$, respectively) and the state of Idaho (5\% in both categories). 
TABLE 3. Reported occurrence of Wood River sculpin in the Wood River basin by U.S. Geological Survey subwatershed. Map number refers to numbered areas in Figure 2.

\begin{tabular}{|c|c|c|c|}
\hline Map no. & Subwatershed name & USGS code & Occurrence \\
\hline 1 & Big Wood River Headwaters & 170402190101 & detected \\
\hline 2 & Anderson Creek-Big Wood River & 170402190102 & detected \\
\hline 3 & Prairie Creek & 170402190103 & detected \\
\hline 4 & Baker Creek & 170402190104 & detected \\
\hline 5 & Boulder Creek-Big Wood River & 170402190105 & detected \\
\hline 6 & Amber Gulch & 170402190106 & detected \\
\hline 7 & Murdock Creek-Big Wood River & 170402190107 & detected \\
\hline 8 & Eagle Creek-Big Wood River & 170402190201 & detected \\
\hline 9 & Lake Creek-Big Wood River & 170402190202 & detected \\
\hline 10 & Elkhorn Gulch-Big Wood River & 170402190203 & detected \\
\hline 11 & Trail Creek & 170402190204 & detected \\
\hline 12 & Corral Creek & 170402190205 & detected \\
\hline 13 & Placer Creek-Warm Springs Creek & 170402190301 & detected \\
\hline 14 & Castle Creek-Warm Springs Creek & 170402190302 & detected \\
\hline 15 & Rock Creek-Warm Springs Creek & 170402190303 & detected \\
\hline 16 & Red Warrior Creek-Warm Springs Creek & 170402190304 & detected \\
\hline 17 & East Fork Big Wood River & 170402190401 & detected \\
\hline 18 & Cove Creek & 170402190402 & detected \\
\hline 19 & Hyndman Creek & 170402190403 & detected \\
\hline 20 & Indian Creek-Big Wood River & 170402190501 & detected \\
\hline 21 & Greenhorn Creek & 170402190502 & detected \\
\hline 22 & Deer Creek & 170402190503 & detected \\
\hline 23 & Croy Creek & 170402190504 & detected \\
\hline 24 & Quigley Creek & 170402190505 & detected \\
\hline 25 & Slaughterhouse Creek-Big Wood River & 170402190601 & detected \\
\hline 26 & Seamans Creek & 170402190602 & potential \\
\hline 27 & Dry Creek & 170402190603 & unknown \\
\hline 28 & Poverty Flat-Big Wood River & 170402190604 & detected \\
\hline 29 & Rock Creek & 170402190605 & detected \\
\hline 30 & Magic Reservoir & 170402190606 & potential \\
\hline 31 & Wedge Butte & 170402190701 & potential \\
\hline 32 & Cottonwood Reservoir-Big Wood River & 170402190702 & unknown \\
\hline 33 & Kinzie Butte-Big Wood River & 170402190703 & potential \\
\hline 34 & Gwinn Cave & 170402190704 & unknown \\
\hline 35 & Milner Gooding Canal-Big Wood River & 170402190705 & unknown \\
\hline 36 & Black Butte Hills & 170402190706 & unknown \\
\hline 37 & Schooler Creek-Thorn Creek & 170402190801 & unknown \\
\hline 38 & High Line Canal-Thorn Creek & 170402190802 & unknown \\
\hline 39 & Preacher Creek & 170402190803 & unknown \\
\hline 40 & Turkey Creek-Big Wood River & 170402190901 & unknown \\
\hline 41 & Tuttle-Big Wood River & 170402190902 & unknown \\
\hline 42 & Fuller-Big Wood River & 170402190903 & unknown \\
\hline 43 & Dry Creek & 170402190904 & unknown \\
\hline 44 & Dog Creek & 170402190905 & unknown \\
\hline 45 & Black Canyon Creek & 170402190906 & unknown \\
\hline 46 & Sheep Creek-Camas Creek & 170402200101 & unknown \\
\hline 47 & Malad River & 170402200102 & unknown \\
\hline 48 & Wildhorse Creek & 170402200103 & unknown \\
\hline 49 & Camas Creek-Camas Prairie & 170402200104 & unknown \\
\hline 50 & Cow Creek & 170402200201 & unknown \\
\hline 51 & No Named Creeks-Camas Creek & 170402200202 & unknown \\
\hline 52 & Chimney Creek & 170402200203 & unknown \\
\hline 53 & Camas Creek & 170402200204 & unknown \\
\hline 54 & Corral Creek & 170402200205 & unknown \\
\hline 55 & Threemile Creek & 170402200206 & unknown \\
\hline 56 & East Fork Three Mile Creek & 170402200207 & unknown \\
\hline 57 & Dairy Creek & 170402200301 & unknown \\
\hline 58 & McKinney Creek & 170402200302 & unknown \\
\hline 59 & Lower Soldier Creek & 170402200303 & potential \\
\hline 60 & Upper Soldier Creek & 170402200304 & detected \\
\hline 61 & Middle Soldier Creek & 170402200305 & detected \\
\hline 62 & Lower Soldier Creek & 170402200306 & detected \\
\hline 63 & Spring Creek & 170402200307 & unknown \\
\hline
\end{tabular}


TABle 3. Continued.

\begin{tabular}{|c|c|c|c|}
\hline Map no. & Subwatershed name & USGS code & Occurrence \\
\hline 64 & Deer Creek & 170402200402 & potential \\
\hline 65 & Elk Creek & 170402200403 & potential \\
\hline 66 & Camas Creek-Poison Creek & 170402200404 & potential \\
\hline 67 & Camp Creek & 170402200405 & potential \\
\hline 68 & Upper Willow Creek & 170402200501 & detected \\
\hline 69 & Middle Willow Creek & 170402200502 & detected \\
\hline 70 & Lower Willow Creek & 170402200503 & detected \\
\hline 71 & Gooding & 170402210101 & unknown \\
\hline 72 & Lower Little Wood River & 170402210102 & detected \\
\hline 73 & Shoshone SW & 170402210103 & unknown \\
\hline 74 & Star Lake & 170402210104 & unknown \\
\hline 75 & Dietrich & 170402210201 & potential \\
\hline 76 & Main Canal & 170402210202 & potential \\
\hline 77 & Shoshone Ice Cave & 170402210203 & unknown \\
\hline 78 & Lower Silver Creek & 170402210301 & detected \\
\hline 79 & Upper Silver Creek & 170402210302 & detected \\
\hline 80 & Little Wood River & 170402210401 & potential \\
\hline 81 & Little Wood River Reservoir & 170402210402 & detected \\
\hline 82 & Howard Reservoir & 170402210403 & potential \\
\hline 83 & Upper Little Wood River & 170402210404 & detected \\
\hline 84 & Baugh Creek & 170402210501 & detected \\
\hline 85 & Upper Little Wood River & 170402210502 & detected \\
\hline 86 & Lower Little Wood River & 170402210503 & detected \\
\hline 87 & Brown Creek & 170402210601 & detected \\
\hline 88 & Lower Muldoon Creek & 170402210602 & detected \\
\hline 89 & Upper Muldoon Creek & 170402210603 & detected \\
\hline 90 & Lower Friedman Creek & 170402210701 & detected \\
\hline 91 & Upper Friedman Creek & 170402210702 & detected \\
\hline 92 & Lower Fish Creek & 170402210801 & detected \\
\hline 93 & Upper Fish Creek & 170402210802 & detected \\
\hline 94 & Huff Lake & 170402210901 & potential \\
\hline 95 & Fish Creek & 170402210902 & detected \\
\hline 96 & Lower Dietrich Main Canal & 170402211001 & unknown \\
\hline 97 & Upper Dietrich Main Canal & 170402211002 & potential \\
\hline 98 & Tapper & 170402211003 & unknown \\
\hline 99 & Pagari & 170402211004 & unknown \\
\hline
\end{tabular}

The proportion of marked sculpins recaptured was calculated for a single upstream pass (lup) and 1 (lupdn), 2 (2updn), and 3 (3updn) bidirectional passes to compare efficiency between electrofishing approaches (Table 5). Mean sampling efficiencies were 0.151 (range $0.000-0.267), 0.286$ (0.000-0.444), 0.398 (0.077$0.593)$, and 0.459 (0.154-0.630) for lup, lupdn, 2 updn, and 3updn passes, respectively. These efficiencies were achieved with averages of $0.164,0.322,0.638$, and 0.942 minutes of electrofishing per $\mathrm{m}^{2}$ of stream surface area, respectively. Sampling efficiency consistently declined with each subsequent pass $(\bar{x}=38 \%)$. Sampling efficiency was significantly greater for large sculpins $(t=2.39, P=0.012)$, and the mean total length of sculpins recaptured in the first pass was significantly greater $(F=$ $8.83, P<0.001)$ than in subsequent passes. No significant differences were observed in mean total length between fish recaptured in the second and third passes.

\section{Discussion}

The sampling events reveal differences in Wood River sculpin distribution between the Idaho Batholith and Snake River Plain ecoregions. Unsurprisingly, most observations were made in Idaho Batholith streams because most sites in the Snake River Plain ecoregion were dry. All but one of the subwatersheds that contain Wood River sculpin detections are at least partially within the Idaho Batholith. The exception is the Little Wood River subwatershed near Shoshone where the lone sampling event occurred in 1893 and from which 2 specimens were retained to describe the species (Gilbert and Evermann 1894). Of the 5 subwatersheds where detections have been followed by only 
TABLE 4. Subwatersheds (USGS codes in parentheses) where additional searches are recommended to ascertain Wood River sculpin occurrence. A summary of the findings from the subwatershed assessment is provided as rationale for additional searches. Subwatersheds listed under no subsequent detections are those where sculpin detections have been followed by nondetections in all of the subsequent sampling events. Subwatersheds listed under potential range are those that border or may be hydrologically connected to subwatersheds with reported detections.

\begin{tabular}{|c|c|}
\hline Subwatershed & Rationale \\
\hline \multicolumn{2}{|l|}{ NO SUBSEQUENT DETECTIONS } \\
\hline Rock Creek (170402190605) & $\begin{array}{l}2 \text { detections between Kent Canyon and Dry Gulch, 1989; } 7 \text { events since (2003-2006), } \\
4 \text { dry }\end{array}$ \\
\hline Prairie Creek (170402190103) & 2 detections below Miner Canyon, 1949 \& 1993; 9 events since (1999-2006), 0 dry \\
\hline Cove Creek (170402190402) & 1 detection in Finley Gulch, 1986; 8 events since (1993-2006); 4 dry \\
\hline Little Wood River (170402210404) & 1 detection between Little Fish Creek and Carey, 1950; 4 events since, 3 dry \\
\hline Silver Creek (170402210301) & 1 detection below Kilpatrick Bridge, 1976; 3 events since, 0 dry \\
\hline \multicolumn{2}{|l|}{ Potential range } \\
\hline Powell Creek (170402200303) & Adjacent to Soldier Creek; 12 events, 2001-2004, 11 dry \\
\hline Deer Creek (170402200402) & $\begin{array}{l}\text { Camas Creek tributary between Soldier and Willow Creeks; } 8 \text { events, (1996-2004), } 8 \\
\text { dry }\end{array}$ \\
\hline Elk Creek (170402200403) & Adjacent to Willow Creek; 7 events, 1976-2005, 6 dry \\
\hline Camp Creek (170402200405) & Adjacent to Willow Creek; 4 events, 1996-2004, 3 dry \\
\hline Poison Creek (170402200404) & Adjacent to Willow Creek; 7 events, 1976-2006, 4 dry \\
\hline Magic Reservoir (170402190606) & Detections at Stanton Crossing; 4 events from tributaries, 2003-2005, 4 dry \\
\hline Big Wood River (170402190701) & Mainstem below Magic Reservoir; 3 events, 1976-2003, 2 dry \\
\hline Big Wood River (170402190703) & $\begin{array}{l}\text { Mainstem between Lincoln Bypass Canal diversion and Highway 75; } 3 \text { events, 1976- } \\
\text { 1996, } 2 \text { dry }\end{array}$ \\
\hline Seamans Creek (170402190602) & Detections in Big Wood River; 1 event, 1995, dry \\
\hline Little Wood River (170402210401) & Detections above Carey; 4 events between Carey and Silver Creek, 2003-2004, 4 dry \\
\hline Little Wood River (170402211002) & $\begin{array}{l}\text { Detections above Carey and at Shoshone; } 6 \text { events between Silver Creek and Jim } \\
\text { Byrns Slough, 1976-2004, } 0 \text { dry }\end{array}$ \\
\hline Little Wood River (170402210202) & $\begin{array}{l}\text { Detections above Carey and at Shoshone; } 8 \text { tributary events between Cottonwood } \\
\text { Slough and Jim Byrns Slough, } 8 \text { dry }\end{array}$ \\
\hline Little Wood River (170402210201) & $\begin{array}{l}\text { Detection at Shoshone; } 3 \text { events between Cottonwood Slough and Shoshone, 1976- } \\
\text { 2003, } 0 \text { dry }\end{array}$ \\
\hline Little Fish Creek (170402210403) & Little Wood River tributary above Carey; 1 event, 2003, 0 dry \\
\hline Fish Creek (170402210901) & Detections in upper Fish Creek; 2 tributary events, 2003-2004, 2 dry \\
\hline
\end{tabular}

TABLE 5. Stream surface area sampled, number of sculpins marked, minutes of cumulative electrofishing effort, and proportion of marked fish recaptured in a single upstream (lup) pass and in 1 (lupdn), 2 (2updn), and 3 (3updn) bidirectional passes.

\begin{tabular}{|c|c|c|c|c|c|c|c|c|c|c|}
\hline \multirow[b]{2}{*}{ Reach } & \multirow[b]{2}{*}{$\begin{array}{l}\text { Area } \\
\left(\mathrm{m}^{2}\right)\end{array}$} & \multirow[b]{2}{*}{$\begin{array}{l}\text { Marked } \\
\text { sculpins }\end{array}$} & \multicolumn{4}{|c|}{ Cumulative effort (minutes) } & \multicolumn{4}{|c|}{ Sampling efficiency (proportion) } \\
\hline & & & lup & lupdn & 2 updn & 3updn & lup & lupdn & 2updn & 3updn \\
\hline $1 \mathrm{~A}$ & 160.0 & 23 & 12.3 & 24.6 & 49.3 & 74.0 & 0.130 & 0.217 & 0.261 & 0.304 \\
\hline 1B & 56.4 & 13 & 5.3 & 10.6 & 21.0 & 31.4 & 0.000 & 0.000 & 0.077 & 0.154 \\
\hline $2 \mathrm{~A}$ & 78.4 & 27 & 13.7 & 23.8 & 47.4 & 68.0 & 0.259 & 0.444 & 0.593 & 0.630 \\
\hline $2 \mathrm{~B}$ & 85.6 & 64 & 8.8 & 17.7 & 35.4 & 53.1 & 0.078 & 0.234 & 0.344 & 0.406 \\
\hline $3 \mathrm{~A}$ & 35.6 & 68 & 10.0 & 19.2 & 37.6 & 54.6 & 0.132 & 0.353 & 0.544 & 0.588 \\
\hline 3B & 40.2 & 100 & 6.4 & 12.6 & 25.2 & 37.4 & 0.050 & 0.150 & 0.310 & 0.410 \\
\hline $4 \mathrm{~A}$ & 26.3 & 18 & 7.7 & 15.2 & 29.4 & 43.7 & 0.167 & 0.389 & 0.444 & 0.611 \\
\hline $4 \mathrm{~B}$ & 50.1 & 26 & 8.5 & 16.9 & 33.3 & 50.2 & 0.115 & 0.231 & 0.385 & 0.423 \\
\hline $5 \mathrm{~A}$ & 62.4 & 177 & 7.7 & 15.5 & 31.3 & 46.6 & 0.243 & 0.316 & 0.418 & 0.492 \\
\hline $5 \mathrm{~B}$ & 48.3 & 131 & 6.8 & 13.3 & 26.5 & 40.0 & 0.267 & 0.344 & 0.496 & 0.557 \\
\hline $6 \mathrm{~A}$ & 34.8 & 30 & 6.3 & 12.9 & 27.2 & 40.2 & 0.233 & 0.367 & 0.500 & 0.500 \\
\hline $6 \mathrm{~B}$ & 48.1 & 25 & 7.2 & 14.6 & 29 & 43.3 & 0.200 & 0.240 & 0.320 & 0.360 \\
\hline 7A & 61.2 & 53 & 11.6 & 21.6 & 41.6 & 57.0 & 0.245 & 0.340 & 0.377 & 0.491 \\
\hline 7B & 27.8 & 8 & 4.6 & 9.3 & 18.4 & 27.7 & 0.000 & 0.375 & 0.500 & 0.500 \\
\hline
\end{tabular}


nondetections, Prairie Creek and lower Silver Creek appear to have the greatest probability of sculpin occurrence today because of more persistent flow. Among subwatersheds classified as potential historical range, the Little Wood River between Silver Creek and Shoshone and Little Fish Creek possibly have the greatest probability of containing sculpins. Additional sampling is needed in these subwatersheds to confirm or refute occupancy.

Estimating sampling efficiency is particularly important in reducing the probability of overlooking species when they are present (Johnson and Sargeant 2002, MacKenzie and Royle 2005). The sampling efficiency observed in this study was similar to sampling efficiences reported by other researchers investigating electrofishing efficiency for sculpins. Based on 2-pass electrofishing using direct current, Heimbuch et al. (1997) reported capture probabilities of 0.393-0.507 for 3 sculpin species. Utzinger et al. (1998) observed electrofishing efficiencies of 0.184 and 0.314 from recaptures of marked bullheads (Cottus gobio) after 3 or 4 upstream passes at 2 sites. The range of efficiencies observed among the sampling approaches and the decline in efficiency between passes indicate that multiple passes during each sampling event and multiple events at each site are needed to estimate absence with a known confidence. Even though sampling efficiency does not equate to detection probability, these results are consistent with MacKenzie and Royle's (2005) recommendation of a minimum of 3 searches when the probability of detecting the species of interest is $\geq 0.5$, and more searches if the probability is $<0.5$. Further work on efficiency of electrofishing sampling for Wood River sculpins in wadeable habitats should account for fish abundance, size, and habitat complexity (Reynolds 1996, Peterson et al. 2004). Investigators may also consider using and evaluating the efficiency of electrofishing discrete channel units with framed devices as described by Bain et al. (1985) and Fisher (1987). Alternative sampling methods may be needed in nonwadeable habitats. Baited minnow traps have been used to collect Shoshone sculpin (Cottus greenei) from nonwadeable springs (Rick Wilkison, Idaho Power Company, personal communication). The efficiency of any alternative sampling method needs to be estimated from a known number of individuals (Dunham et al. 2009).

\section{ACKNOWLEDGMENTS}

Funding was provided by the Bureau of Land Management (Assistance Agreement No. DLA040219), the U.S. Environmental Protection Agency (Assistance Agreement No. X797083001-0), the Idaho Department of Environmental Quality, the Lava Lake Institute for Science and Conservation, and The Nature Conservancy. The Idaho Department of Environmental Quality conducted the mark-recapture data collection and provided support with administration, geographic information, and field staff. Staff members from the Wood River Land Trust, The Nature Conservancy, and the Bureau of Land Management assisted with data collections. R. Thurow and J. Guzevich of the USDA Forest Service, Rocky Mountain Research Station, Boise Aquatic Sciences Lab, assisted with the planning and provided equipment for the mark-recapture work. Taxonomic verifications were made and specimens archived at the Orma J. Smith Museum of Natural History, College of Idaho. Protocol 2004-74 of the University of Idaho Animal Care and Use Committee was developed with the assistance of B. Williams at the University of Idaho. This manuscript was greatly improved by the reviews of J.M. Scott, J. Congleton, R. Hughes, T. Cochnauer, $\mathrm{M}$. Young, and 2 anonymous reviewers. Citation in this document does not imply endorsement by the organizations involved.

\section{Literature Cited}

Abbruzzese, C., And R. Henderson. 1999. Fish surveys for redband trout in the Big and Little Wood river drainages. USDA Forest Service Sawtooth National Forest and Sawtooth National Recreation Area, Ketchum, ID. $116 \mathrm{pp}$.

BAIN, M.B. J.T. FINN, AND H.E. Booke. 1985. A quantitative method for sampling riverine microhabitats by electrofishing. North American Journal of Fisheries Management 5:489-493.

Bayley, P.B., And J.T. Peterson. 2001. An approach to estimate probability of presence and richness of fish species. Transactions of the American Fisheries Society 130:620-633.

Bond, C.E. 1963. Distribution and ecology of freshwater sculpins, genus Cottus, in Oregon. Doctoral dissertation, University of Michigan, Ann Arbor, MI. 186 pp.

Buhidar, B.B. 2002. The Big Wood River management plan. Twin Falls Regional Office, Idaho Department of Environmental Quality, Twin Falls, ID. 206 pp.

Claire, J. 2005a. Camas Creek subbasin assessment and total maximum daily load. Twin Falls Regional Office, Idaho Department of Environmental Quality, Twin Falls, ID. $280 \mathrm{pp}$.

2005b. Little Wood River subbasin assessment and TMDL. Twin Falls Regional Office, Idaho Department of Environmental Quality, Twin Falls, ID. 255 pp. 
Dunham, J.B., A.E. Rosenberger, R.F. Thurow, C.A Dolloff, AND P.J. Howell. 2009. Coldwater fish in wadeable streams. Pages 119-138 in S.A. Bonar, W.A Hubert, and D.W. Willis, editors, Standard methods for sampling North American freshwater fishes. American Fisheries Society, Bethesda, MD.

Fisher, W.L. 1987. Benthic fish sampler for use in riffle habitats. Transactions of the American Fisheries Society 116:768-772.

Gilbert, C.H., AND B.W. Evermann. 1894. A report upon investigations in the Columbia River basin, with descriptions of four new species of fishes. Bulletin of the United States Fish Commission 14 (for 1894): 169-207. U.S. Government Printing Office, Washington, DC.

Heimbuch, D.G., H.T. Wilson, S.B. Weisberg, J.H. VøLSTAD, AND P.F. KAZYAK. 1997. Estimating fish abundance in stream surveys by using double-pass removal sampling. Transactions of the American Fisheries Society 126:795-803.

Herlihy, A.T., D.P. Larsen, S.G. Paulsen, N.S. Urouhart, AND B.J. Rosenbaum. 2000. Designing a spatially balanced, randomized site selection process for regional stream surveys: the EMAP mid-Atlantic pilot study. Environmental Monitoring and Assessment 63:95-113.

Hughes, R.M., AND J.M. OMERNIK. 1981. Use and misuse of the terms watershed and stream order. Pages 320 326 in L.A. Krumholz, editor, The warmwater streams symposium. Southern Division American Fisheries Society, Bethesda, MD.

IDAHO DEPARTMENT OF FISH AND GAME. 2005. Idaho comprehensive wildlife conservation strategy. Idaho Conservation Data Center, Boise, ID. Available from: http://fishandgame.idaho.gove/cms/tech/CDC/cwcs.cfm

IdAho Department of Water ResourCes. 2007. Subbasins (IDWR-Draft), edition 1. Boise, ID; [metadata: 13 September 2007]. Available from: http://www.idwr .state.id.us/ftp/gisdata/Spatial/Watersheds/wtrshed .shp.xml

2008. Idaho subwatersheds (sixth fields). Available from: http://www.idwr.idaho.gov/GeographicInfo/ gisdata/watersheds.htm

Johnson, D.H., AND G.A. SARGEAnT. 2002. Toward better atlases: improving presence-absence information. Pages 391-397 in J.M. Scott, P.J. Heglund, M.L. Morrison, J.B. Haufler, M.G. Raphael, W.A. Wall, and F.B. Samson, editors, Predicting species occurrences: issues of accuracy and scale. Island Press, Washington, DC

Jones, A.C. 1972. Contributions to the life history of the Piute sculpin in Sagehen Creek, California. California Fish and Game 58:285-290.

LandSCAPE Dynamics Lab. 1999. Stewardship and conservation status of Idaho. Idaho Cooperative Fish and Wildlife Research Unit, Moscow, ID. Available from: http://data.insideidaho.org/data/icfwru/archive/steward id icfwru.zip

MACKENZIE, D.I. 2005. What are the issues with presence-absence data for wildlife managers? Journal of Wildlife Management 69:849-860.

MacKenzie, D.I., J.D. Nichols, G.B. Lachman, S. Droege, J.A. Royle, and C.A. Langtimm. 2002. Estimating site occupancy rates when detection probabilities are less than one. Ecology 83:2248-2255.

MacKenzie, D.I., AND J.A. Royle. 2005. Designing occupancy studies: general advice and allocating survey effort. Journal of Applied Ecology 42:1105-1114.
McGrath, C.L., A.J. Woods, J.M. OMernik, S.A. Bryce, M Edmondson, J.A. Nesser, J. Shelden, R.C. CrawFORD, J.A. COMSTOCK, AND M.D. Plocher. 2001. Ecoregions of Idaho [color poster with map, descriptive text, summary tables, and photographs]. Map scale 1:1,350,000. U.S. Geological Survey, Reston, VA.

McKenney, D.W., L.A. Venier, A. Heerdegen, and M.A McCarthy. 2002. A Monte Carlo experiment for species mapping problems. Pages 377-381 in J.M. Scott, P.J. Heglund, M.L. Morrison, J.B. Haufler, M.G. Raphael, W.A. Wall, and F.B. Samson, editors, Predicting species occurrences: issues of accuracy and scale. Island Press, Washington, DC.

Merkley, K., AND J.S. GRIFFITH. 1993. Densities and habitat utilization of Wood River sculpin (Cottus leiopomus) on three Nature Conservancy preserves in Idaho. Idaho State University, Pocatello, ID. 37 pp.

Meyer, K.A., D.J. SCHill, M.R. CAMPBEll, AND C.C. KOZFKAY. 2008. Distribution, abundance, and genetic population structure of Wood River sculpin, Cottus leiopomus. Western North American Naturalist 68: 508-520.

Moyle, P.B., AND J.J. CECH, JR. 2000. Fishes: an introduction to ichthyology. 4th edition. Prentice Hall, Upper Saddle River, NJ.

Olsen, A.R., AND D.V. Peck. 2008. Survey design and extent estimates for the wadeable streams assessment. Journal of the North American Benthological Society 27:822 836.

Oregon State University. 1998. Average yearly precipitation. Water and Climate Center of the Natural Resources Conservation Service, Portland, OR; [metadata: 21 September 2006]. Available from: http://www .ocs.orst.edu/prism/prism new.html

Peterson, J.T., R.F. Thurow, AÑ J.W. GuZevich. 2004. An evaluation of multipass electrofishing for estimating the abundance of stream-dwelling salmonids. Transactions of the American Fisheries Society 133:462-475.

Reynolds, J.B. 1996. Electrofishing. Pages 221-253 in B.R. Murphy and D.W. Willis, editors, Fisheries techniques. 2nd edition. American Fisheries Society, Bethesda, MD.

Simpson, J.C., AND R.L. Wallace. 1982. Fishes of Idaho. University of Idaho Press, Moscow, ID. 238 pp.

Strahler, A.N. 1957. Quantitative analysis of watershed geomorphology. Transactions, American Geophysical Union 38:913-920.

Tyre, A.J., B. Tenhumberg, S.A. Field, D. Niejalke, K. PARRIS, AND H.P. PossinghaM. 2003. Improving precision and reducing bias in biological surveys: estimating false-negative error rates. Ecological Applications 13:1790-1801.

[USGS AND USDA-NCS] U.S. GEOLOGICAL SURVEY AND U.S. Department of Agriculture, Natural Resources Conservation Service. 2009. Federal guidelines, requirements, and procedures for the National Watershed Boundary Dataset. U.S. Geological Survey Techniques and Methods 11-A3, Reston, VA. 55 pp.

Utzinger, J., C. Roth, and A. Peter. 1998. Effects of environmental parameters on the distribution of bullhead Cottus gobio with particular consideration of the effects of obstructions. Journal of Applied Ecology 35:882-892.

Received 25 June 2009

Accepted 4 August 2010 